\title{
Karolina Nikielska*
}

\author{
KOBIECOŚĆ, ZASŁONA I PATRIARCHAT \\ W DEMOKRATYCZNEJ REPUBLICE TURECKIEJ, \\ CZYLI KIM JEST WSPÓŁCZESNA TURCZYNKA
}

\begin{abstract}
W artykule analizuję sytuację kobiet we współczesnej Republice Tureckiej w kontekście procesów sekularyzacji i modernizacji, ale także patriarchalnej obyczajowości muzułmańskiej, które równocześnie kształtują światopogląd obywateli tego państwa. Przedstawiam przemianę ideału kobiety, dokonaną za sprawą sekularyzacji państwa tureckiego. Koncentruję się także na kwestii zasłony muzułmańskiej, która za sprawą funkcjonujących w Turcji dyskursów - tradycyjnego i nowoczesnego - urosła do rangi symbolu o wielu znaczeniach. W swojej analizie uwzględniam zarówno rolę modernizacji w kreowaniu sposobów myślenia obywateli, jak i islamu, który znikając z przestrzeni publicznej, pozostał ważnym czynnikiem determinującym światopogląd Turków. Powołuję się także na wyniki badań własnych dotyczących sposobów postrzegania chusty muzułmańskiej przez nowoczesne Turczynki. Pierwsza część artykułu jest prezentacją sytuacji historycznej Turcji ze szczególnym uwzględnieniem przemian, które dokonały się za sprawą reform Mustafy Kemala Atatürka. Analizuję w niej rolę kobiet w Turcji na tle wydarzeń historycznych. Następnie przechodzę do rozważań dotyczących wkraczania kobiet w sferę publiczną i towarzyszących temu zmian obyczajowych oraz napięć powstających w świadomości „nowych” Turczynek. W drugiej części artykułu opisuję wyniki badań własnych, dotyczących sposobów postrzegania chusty muzułmańskiej wśród grupy młodych studentek jednego ze stambulskich uniwersytetów, pokazując, w jaki sposób napięcia w tożsamości, opisywane w Tureckiej literaturze przedmiotu, widoczne są w wypowiedziach respondentek. Nawiązuję także do polisymboliczności zasłony, której znaczenie wykroczyło poza kontekst religijny.
\end{abstract}

Słowa kluczowe: islam, kobiecość, religijność, zasłona muzułmańska

W dobie przemian globalizacyjnych religijność w społeczeństwach, które jeszcze niedawno można było zakwalifikować jako tradycyjne, przybiera wiele różnych form. Procesy sekularyzacji prowadzą do osłabienia religijności zinstytucjonalizowanej na rzecz jej prywatyzacji. W zachodnich nowoczesnych państwach szeroko dyskutowane są procesy odchodzenia od religijności w ogóle. Również Turcja jest przykładem takiego społeczeństwa, w którym bardzo tradycyjna religijność muzułmańska jest transformowana przez silne procesy sekularyzacyjne. Światopogląd społeczeństwa tureckiego kształtowany jest obecnie zarówno przez islam, jak i przez sekularyzację, co powoduje liczne napięcia w wymiarze tożsamości tureckiej. Na tożsamość tę bowiem składa się zarówno identyfikacja z ideologią muzułmańską, jak i z kemalistycznymi ideami westernizacji.

* AGH Akademia Górniczo-Hutnicza; karolinanikielska@gmail.com 
W niniejszym artykule zamierzam zaprezentować napięcia $\mathrm{w}$ tożsamości tureckich kobiet, wynikające z pozostawania przez nie pod wpływem dwóch odmiennych dyskursów: tradycyjnego muzułmańskiego oraz nowoczesnego kemalistycznego. Przedstawię przemianę ideału kobiety, która dokonała się za sprawą sekularyzacji państwa tureckiego, pokazując równocześnie, jakie znaczenia miała ta przemiana dla sposobu funkcjonowania społeczeństwa. Opowiem o islamie, który mimo że podczas modernizacji zniknął z przestrzeni publicznej państwa, pozostał ważnym kreatorem światopoglądu Turków. Końcowa część artykułu prezentuje wyniki badań własnych, dotyczących sposobów postrzegania chusty muzułmańskiej przez nowoczesne Turczynki.

\section{OD PATRIARCHATU DO REPUBLIKI DEMOKRATYCZNEJ. PRZEMIANY USTROJOWE TURCJI}

Turcja jest krajem, który przeszedł gwałtowną przemianę ustrojową, z dnia na dzień przeobrażając się $\mathrm{z}$ islamskiego państwa $\mathrm{w}$ demokratyczną republikę. Pierwszym, bardzo ważnym wstępem do sekularyzacji i westernizacji był okres tanzimatu - czas reform społecznych, kulturalnych i politycznych w Turcji, przypadający na lata 1839-1876 (Ahmad 2003). Najważniejsze zmiany jednak, będące obietnicą lepszego, nowoczesnego życia na modłę europejska, przyniosło dopiero proklamowanie nowego ustroju demokratycznego przez pierwszego prezydenta Republiki Tureckiej, Mustafę Kemala Atatürka, 29 października 1923 roku. Wkrótce po tym wydarzeniu Kemal zaczął wprowadzać kolejne reformy, zmieniając kraj i przyzwyczajenia jego obywateli. Uchwalona w 1925 roku „ustawa kapeluszowa” pod groźbą kary śmierci zakazywała noszenia tradycyjnych, tureckich nakryć głowy na rzecz europejskich kapeluszy. Nawoływała także do europeizacji stroju kobiecego. Jej znaczenie jednak wykraczało daleko poza tytułowy „kapelusz”, ponieważ była wezwaniem nie tylko do zmiany sposobu ubioru, lecz przede wszystkim do zmiany obyczajów (Chmielowska, K1liç-Ery1lmaz 2001). W 1926 roku wprowadzono w Turcji kodeks cywilny, odpowiadający kodeksowi szwajcarskiemu. Dokument ten zrównał w prawach kobiety i mężczyzn. Nakazywał odbywanie ceremonii zaślubin w obecności odpowiedniego urzędnika, dawał kobiecie prawo do przyjęcia lub odrzucenia nazwiska męża, zabraniał poligamii, a także dawał możliwość rozwodu na wniosek każdej ze stron (Chmielowska, K1liç-Eryılmaz 2001).W roku 1930 i 1934 przyznano kobietom bierne, a później czynne prawa wyborcze do parlamentu. Otwarto im także drogę do edukacji na każdym szczeblu. Prawodawstwo tureckie za sprawą

\footnotetext{
W 1839 i 1856 roku wydano kolejno dwie karty królewskie („,The Charter of the Rose Chamber”), zawierające deklarację reform, które uważane są za pierwszy poważny krok w stronę modernizacji państwa. Zapewniały one równość wszystkim poddanym sułtana, w szczególności równość wyznawców różnych religii, a także przywilej sądzenia przez instytucje prawne dla każdego obywatela (Ahmad 2003: 33-35). Towarzyszące tanzimatowi reformy edukacji wprowadziły powszechne szkolnictwo średnie i wyższe, co miało duże znaczenia dla poprawy sytuacji kobiet w kraju (Chmielowska, Kılıç-Eryılmaz 2001). Z drugiej strony jednak tanzimat nie był epoką pozbawioną absurdów związanych z pozycją kobiety. W rejestrze obywateli kobiety pytane były jedynie o nazwisko, wiek i krewnych, podczas gdy spis mężczyzn zawierał takie detale jak kolor włosów, oczu, waga czy noszenie brody (Göle 1996).
} 
Atatürka zaczynało przypominać prawodawstwo zeuropeizowanego kraju zapewniającego równość i swobody wszystkim obywatelom. Sam Atatürk natomiast swoim zachowaniem przyczyniał się do stopniowej zmiany tureckich obyczajów opartych na tradycji patriarchalnej. Przykładowo podczas jednego z balów zachęcał kobiety do tańca z oficerami tureckimi, przełamując tabu kontaktu fizycznego kobiety i mężczyzny w sferze publicznej (Göle 1996).

Przed okresem tanzimatu, a szczególnie przed reformami Atatürka, obyczajowość turecka była silnie związane z tradycją muzułmańską, napływającą wraz z ekspansją islamu ze Wschodu, a także z systemem patriarchalnym przejętym od Persów. Dominacja mężczyzn i wyraźne wykluczenie kobiet ze sfery publicznej nie od zawsze jednak stanowiły cechy konstytutywne tureckiej kultury i społeczeństwa. Jak podają źródła z VIII wieku n.e., ówczesne społeczeństwo tureckie nie znało patriarchatu. Odpowiedzialność za dom i rodzinę spoczywała równorzędnie na obu małżonkach, a narodziny dziewczynki miały taką samą wartość jak narodziny chłopca. Przyjęty w IX wieku w Turcji islam, który blisko dwieście lat wcześniej poprawił sytuację kobiet na Półwyspie Arabskim, w kraju nad Bosforem przyniósł odwrotny skutek, znacznie ograniczając swobodę tureckich kobiet (Chmielowska, Kılıç-Eryılmaz 2001; Machut-Mendecka 2001). W XV wieku wprowadzono życie haremowe, natomiast począwszy od wieku XVI zaczęły pojawiać się kolejne dotyczące kobiet dekrety², które na początku wieku XIX doprowadziły do niemal całkowitego zniknięcia przedstawicielek płci żeńskiej z przestrzeni publicznej.

Zmiany, które zaszły od czasów dżahilijji do połowy XIX wieku, mimo że stopniowe, zasługują na miano drastycznych ze względu na swoją treść. Równość płci, pełne prawa i swobody przysługujące kobietom na przestrzeni dziesięciu wieków zostały zaprzepaszczone. Przedstawicielki płci żeńskiej, całkowicie podporządkowane patriarchalnemu światu, zależne decyzyjnie i materialnie od mężczyzn, stały się nieobecne w świecie społecznym. Ich miejscem i polem działania stał się dom.

\section{ATATÜRK I JEGO WIZJA ZSEKULARYZOWANEGO PAŃSTWA A OBECNOŚĆ KOBIET W SFERZE PUBLICZNEJ}

Proklamowanie republiki tureckiej i takie reformy przeprowadzone przez Mustafę Kemala, jak wprowadzenie koedukacyjnego szkolnictwa i praw politycznych dla obu płci, konsekwentnie przyczyniły się do fizycznej i publicznej obecności kobiet w świecie społecznym. Kobiety mogły funkcjonować bez przeszkód w jednej przestrzeni z mężczyznami, pracując samodzielnie w różnych zawodach (Durakbaşa 1997). Mogły także pojawiać się na przyjęciach oraz udzielać się charytatywnie. W ten sposób jedna z misji Atatürka - społeczna widoczność

\footnotetext{
2 Przykładowo zakaz przebywania kobiet na jednej łodzi z mężczyznami (1572 r.), ustalenie maksymalnej liczby wyjść kobiety na ulicę do czterech razy w tygodniu (1790 r.), a później zakaz wychodzenia w ogóle, nawet w towarzystwie męża lub ojca (1807 r.). Ograniczenia dotyczyły również stroju. Jeżeli kobieta w ogóle pojawiała się na ulicy, jej ciało musiało być zakryte. Stroje musiały być uszyte z grubego, nieprześwitującego materiału. Krawcy, pod groźbą powieszenia, nie mogli szyć kobietom strojów z delikatnych, cienkich materiałów (1754 r.) (Chmielowska, Kılıç-Eryılmaz 2001).
} 
kobiety - została wypełniona (Göle 1996). Jednak wkroczenie do przestrzeni publicznej kobiet obwarowane zostało określonymi wymogami. Przede wszystkim tradycyjny kobiecy strój musiał zostać zamieniony na nowoczesny i europejski - o muzułmańskich chustach nie mogło być mowy. Kobiece ciało powinno być zdrowe, czyli zgodnie z obowiązującymi wówczas definicjami: szczupłe i wysportowane, a zatem zbieżne z zachodnim kanonem urody (Göle 1996; Durakbaşa 1997). Tego wymagał ówczesny polityczny dyskurs oparty na ideach sekularyzacji państwa, do którego kobiety musiały się dopasować. Z drugiej jednak strony przedstawicielki płci żeńskiej znajdowały się pod wpływem wciąż silnej patriarchalnej obyczajowości tureckiej, w której najwyżej cenioną wartością był męski honor - şeref- oceniany na podstawie cnoty, skromności i powściągliwości seksualnej należących do rodziny mężczyzny kobiet. Na skutek dualnego wpływu modernizacji i obyczajowości patriarchalnej pomiędzy córkami (kobietami) i ich ojcami (mężczyznami opiekunami) powstał niepisany układ - w zamian za możliwość edukacji i swobodę funkcjonowania w sferze publicznej kobieta zobowiązywała się utrzymać swoją seksualność pod kontrolą aż do momentu, w którym rodzina znalazła dla niej odpowiedniego męża. W efekcie musiała ona zamienić się w superbohaterkę, która potrafi pogodzić ze sobą sprzeczne role - społecznie aktywnej i wyedukowanej profesjonalistki, reproduktorki funkcjonującej biologicznie i prowadzącej gospodarstwo domowe oraz uroczej kobietki zabawiającej mężczyzn na przyjęciach (Durakbaşa 1997).

Nowa kobieta turecka była odpowiedzialna za siebie, swoją rodzinę i państwo. Dbała o rodzimą gospodarkę, kupując wyłącznie tureckie produkty (Durakbaşa 1997), nie wydawała pieniędzy bez zastanowienia. Była więc przede wszystkim matką sprawującą odpowiedzialne funkcje w społeczeństwie, związane z przekazywaniem młodszym pokoleniom tożsamości narodowej i odpowiedzialności za kraj. Jako pierwsza wychowawczyni i nauczycielka dzieci uważana była nie tylko za reproduktorkę biologiczną, lecz także kulturową oraz symboliczną matkę narodu (Anthias, Yuval-Davis 1989). Szanowana, niedostępna i pozbawiona seksualności w sferze publicznej realizowała ideał kobiecości narzucony przez dyskurs kemalistyczny, pozostając jednocześnie w zgodzie z najważniejszymi wartościami obyczajowości patriarchalnej (Erdoğlu Erkarslan 2011).

Na skutek silnych procesów zeświecczenia państwa islam, mimo że znikał z przestrzeni publicznej, paradoksalnie stał się bardzo ważnym elementem sekularyzacji, określając to, kto jest nowoczesny, a kto nie. Powstała silna dychotomia pomiędzy nowoczesnym kemalistą a islamistą (Raudvere 2003). Podobnie jak w czasie rewolucji irańskiej w latach 1978-1979 czarczaf, tak podczas modernizacji w Turcji chusta muzułmańska stała się symbolem politycznym (Göle 1996). Tureckie kobiety przeszły radykalną przemianę, upodobniając się do swoich koleżanek z Zachodu. Ich seksualność jednak w dalszym ciągu pozostawała pod kontrolą mężczyzn, podobnie jak przez stulecia kontrolowana była za pomocą muzułmańskiego stroju. Obok wkraczających w przestrzeń publiczną nowoczesnych kobiet pojawiły się także te, noszące chusty, które również chciały funkcjonować w społeczeństwie na wywalczonych w drodze emancypacji zasadach (Göle 1996). Ponieważ jednak nie pasowały wizualnie do nowego obrazu świeckiego państwa, ich działania uznawane były za zagrażające demokracji, co szybko wpłynęło na niechęć kemalistów i kemalistek względem tradycyjnych muzułmanek i muzułmanów. 


\section{METODA I KONTEKST BADAŃ}

Mając na uwadze złożoność problemów towarzyszących procesom modernizacji w Turcji, postanowiłam przeprowadzić badania nad religijnością młodych, nowoczesnych Turczynek. W niniejszym artykule, ze względu na ograniczenia objętościowe, zaprezentuję jedynie ich fragment ${ }^{3}$. Sprawdzę, jakie znaczenie mają kemalistyczny dyskurs polityczny i tradycyjny dyskurs religijny w kształtowaniu poglądów i religijności respondentek. Zajmę się analizą sposobów postrzegania przez respondentki muzułmanek zakładających chusty, a także przyglądnę się znaczeniom przypisywanym przez nie chuście muzułmańskiej.

Swoje badania przeprowadziłam w grupie piętnastu studentek Uniwersytetu Yeditepe w Stambule. Do udziału w nich mogłam zaprosić każdą studentkę, która deklarowała się jako muzułmanka sunnitka lub pochodziła z rodziny o tradycjach sunnickich, w której przynajmniej jeden z rodziców lub dziadków identyfikował się z islamem sunnickim. Początkowo inspirację metodologiczną badań stanowiła teoria ugruntowana Anselma Straussa i Barneya Glasera, która podczas przeprowadzania obserwacji badanego środowiska uzupełniona została przez kategorie teoretyczne. Ostatecznie, formułując założenia badawcze, oparłam się na wiedzy empirycznej, zdobytej podczas obserwacji, oficjalnej doktrynie islamu oraz tureckich i innych badaniach, a także na publikacjach dotyczących kwestii kobiet w Turcji. Zastosowaną przeze mnie metodą badawczą był wywiad pogłębiony, który pozwalał na zaaplikowanie do badań podejścia humanistycznego i związanego z nim emocjonalizmu, zakładającego zrozumienie i empatię pomiędzy badaczką a respondentką (Silverman 2009). Pytania badawcze, które stawiam przed sobą w niniejszym artykule, brzmią następująco: w jaki sposób nowoczesne kobiety w zsekularyzowanym, ale równocześnie mocno kształtowanym przez islam kraju, odnoszą się do kwestii zakrywania głów muzułmańskimi chustami? Czy w wypowiedziach wykształconych przedstawicielek płci żeńskiej widoczne są echa konfliktu pomiędzy wyznawcami idei kemalistycznych a tradycyjnymi muzułmanami? Jaką symbolikę przyjmuje w wypowiedziach respondentek chusta muzułmańska?

Stambuł, miasto, w którym prowadziłam badania, jest jedną z największych pod względem liczby ludności metropolią świata. Jego blisko 15 -milionowa ${ }^{4}$ populacja to ludzie pochodzący ze wszystkich zakątków Turcji i z każdej klasy ekonomiczno-społecznej. To miasto trzech imperiów, rozdarte między Europą a Azją nie tylko geograficznie, ale i mentalnie. Miasto pełne kompleksów w stosunku do Zachodu, ale i pełne aspiracji. Na stambulskich ulicach

Badania w pełnej wersji dotyczyły obrazu religijności młodych tureckich kobiet. Religijność mierzona była za pomocą wymiarów religijności Rodneya Starka i Charlesa Glocka (1968), do których dobrałam wskaźniki, posługując się wytycznymi oficjalnej doktryny islamu. Pytałam respondentki o zagadnienia związane z dogmatami islamu oraz autoidentyfikacją religijną, kwestie przestrzegania praktyk i rytuałów religijnych, następnie przechodziłam do doświadczeń religijnych, zagadnień etycznych i moralnych, dalej poruszałam problemy związane z pozycją kobiety w społeczeństwie. Na końcu pytałam o wiedzę na temat religii. Pytanie badawcze, które sobie zadałam, przystępując do badań, brzmiało: „Jaka jest religijność młodych kobiet w Turcji?” Jednym z najważniejszych wniosków z moich badań było twierdzenie o prywatyzacji religijności wśród respondentek, odwoływanie się przez badane w wykonywaniu praktyk religijnych bardziej do tradycji i obyczajowości ludowej niż do oficjalnej doktryny religijnej oraz wyraźna heterodoksja poglądów religijnych.

4 Za Agnieszką Aysen Kaim, turkolożką z Uniwersytetu Warszawskiego (za: Mazurczyk 2009). Różne źródła podaja jednak odmienne dane. 
można spotkać każdego - od pucybuta przez sprzątacza, urzędnika państwowego po biznesmena, arystokratę i milionera. Zróżnicowanie ludności dotyczy jednak nie tylko statusu ekonomicznego, lecz także szeroko pojętego światopoglądu. Mieszkają tutaj Turcy zarówno bardzo tradycyjni, jak i kosmopolityczni, zeuropeizowani.

Uniwersytet Yeditepe położony jest w azjatyckiej części miasta, w tradycyjnej, stosunkowo nowej, wciąż rozbudowującej się i przyjmującej przybyszów z mniejszych miast dzielnicy, w sąsiedztwie kosmopolitycznego Kadiköy. Stanowi ogromny kontrast dla swojego otoczenia. Na pierwszy rzut oka nowoczesny kampus wpisuje się w nowe budownictwo okolicy, jednak ludzie przechodzący przez bramy uniwersytetu znacznie różnią się od przechadzających się pobliskimi ulicami. Różnica ta dotyczy stroju i, jak twierdzą studenci i studentki, towarzyszącego mu sposobu życia. Na terenie uczelni spotyka się pięknych, modnie i drogo ubranych młodych ludzi. Na parkingu uniwersyteckim dla studentów stoją luksusowe samochody, które świadczą o zamożności uczniów. Sam uniwersytet jest placówką prywatną z bardzo wysokim czesnym za naukę ${ }^{5}$ W momencie przeprowadzania badań na terenie kampusu zgodnie z prawem obowiązywała neutralność religijna w stroju - nie było miejsca dla kobiet zakrywających włosy chustą ${ }^{6}$. Nie oznacza to jednak, że takie się tam nie pojawiały. Spotykałam dziewczyny w perukach, pod którymi widoczne były kolorowe chustki. Było ich niewiele, jednak na tyle dużo, że zjawisko to było zauważalne i dyskutowane przez studentki i studentów. Kobiety te jednak przebywały głównie w swoim towarzystwie i bardzo trudno było nawiązać z nimi kontakt. Akademiki Yeditepe nie zakładały koedukacji. Mężczyźni nie mieli wstępu na teren żeńskiego akademika i odwrotnie. Ci, którzy odważyli się wejść za drzwi, byli wypraszani przez portierki. W samym akademiku panowały surowe reguły dotyczące wieczornych powrotów, przestrzegane przez studentki. Portierki pilnowały także moralności mieszkanek, pytając o powody wyjścia, a także upominając dziewczyny, które zbyt często (niekoniecznie w nocy) opuszczały akademik. Nowoczesność Yeditepe z jednej strony i współistniejąca troska o moralność studentek, typowa dla tradycji patriarchalnej, z drugiej, to wyraźny przykład przenikania się dwóch dyskursów - kemalistycznego i muzułmańskiego, które wspólnie ukształtowały nie tylko charakter uniwersytetu i podlegających mu jednostek, lecz także obraz współczesnej Turcji.

\section{ZASŁONA MUZUŁMAŃSKA I JEJ ZNACZENIA NA TLE DYSKURSÓW POLITYCZNEGO I RELIGIJNEGO W TURCJI}

Wygląd zewnętrzny kobiety, szczególnie jej strój, był bardzo ważnym elementem w procesach sekularyzacji i westernizacji Turcji. Chcąc sprawdzić, w jaki sposób respondentki odnoszą się do kontrowersyjnej kwestii kobiecego ubioru, poprosiłam badane o wypowiedź na temat damskiej odzieży. Zapytałam, w jaki sposób ich zdaniem powinna ubierać się kobieta. Na podstawie udzielonych odpowiedzi wnioskuję, że studentki dopuszczały dużą swobodę

5 Opłaty za semestr nauki w Yeditepe wynoszą, zależnie od kierunku od 5400 USD do nawet 38000 USD; źródło: http://www.yeditepe.edu.tr/ogrenci-kabul/ucretler [3.04.2012].

6 W grudniu 2010 roku prawie wszystkie uniwersytety tureckie porzuciły oficjalny zakaz noszenia islamskich chust na swoich kampusach. Więcej na ten temat tutaj: http://www.bbc.co.uk/news/world-europe-11880622; http://www.care2.com/causes/turkey-ends-ban-on-headscarves-in-universities.html [30.03.2012]. 
w wyglądzie zewnętrznym Turczynki. Większość z nich mówiła, że kobieta może nosić, co zechce. Kilka zwróciło uwagę na kwestie związane z bezpieczeństwem. Jedna wypowiedziała się w ten sposób:

Dla mnie [sposób ubioru - przypis autorki] to kwestia bezpieczeństwa. Jest wielu mężczyzn w Turcji... Niektórzy ludzie... Więc... w Stambule żyją ludzie z obszarów wiejskich... Mogą za tobą podążać... mogą zrobić jakąś zaporę [zastąpić drogę - przypis autorki]... To wybór osobisty, ale ja staram się nie nosić czegoś całkowicie odkrywającego... Robiąc tak, chronisz siebie. Jeśli jest wystarczająco dużo ludzi do ochronienia mnie, wtedy nie dbam o strój! (R3).

Wszystkie respondentki preferują stroje zachodnie, tak też każda była ubrana podczas wywiadu. Jedna z nich twierdzi, że stara się nosić nieco luźne ubrania, łącząc zalecenia islamu z modą na swój indywidualny sposób. Część rozmówczyń bardzo ostro krytykowała kobiety noszące tradycyjne stroje muzułmańskie - szczególnie szaty w kolorze czarnym, zakrywające całe ciało i z obowiązkowym nikabem. Wśród krytykujących znajdowały się zarówno muzułmanki, jak i niedeklarujące przynależności do żadnej religii. Wyjątkową tolerancję na strój kobiety i na kwestię noszenia chust, którą omówię poniżej, wykazywały studentki antropologii. Wydaje się, że przyczyną był właśnie kierunek studiów.

Nowoczesny strój badanych oraz przyznanie kobiecie prawa do samodzielnego decydowania o własnym ubiorze jest wyraźnym znakiem modernizacji, która dokonała się w Turcji. Z drugiej strony strach przed obcymi mężczyznami, potrzeba ochrony swojego ciała, czy próby sprostania wymogom dwóch sprzecznych dyskursów potwierdzają stały wpływ patriarchatu na życie codzienne w Turcji. Uzależnienie własnego bezpieczeństwa od sposobu ubioru wprost odnosi się do kwestii samokontroli kobiet w przestrzeni publicznej poprzez strój, który równocześnie wyznacza granice $\mathrm{w}$ relacji z mężczyzną. Taka ideologia wywodzi się z tradycji muzułmańskiej: burka oraz jej pochodne pełnią rolę granicy dozwolonego, przyzwoitego zachowania mężczyzny, będąc paradoksalnie formą męskiej samokontroli w przestrzeni publicznej (Göle 2001). Respondentki są więc przedstawicielkami „nowych kobiet” - już nie religijnych, ale też nie do końca zmodernizowanych, żyjących w nowoczesnym świecie, lecz znajdujących się wciąż pod wpływem tradycyjnej obyczajowości tureckiej.

Kwestia zasłony budziła ogromne kontrowersje wśród moich rozmówczyń, szczególnie wśród wykazujących kemalistyczne poglądy studentek innych kierunków niż antropologia. Biorąc pod uwagę rolę i znaczenie, jakie zasłona pełniła w czasach przemian modernizacyjnych w Turcji, fakt ten nie powinien dziwić. Trzy spośród badanych wyraźnie popierały idee zasłony w religii muzułmańskiej. Pozostałe dzieliły się na dwie grupy: pierwsza, uznająca, że zakładanie chusty jest kwestią osobistej decyzji oraz druga zdecydowanie opowiadająca się przeciwko noszeniu zasłony przez kobiety ${ }^{7}$. Grupa pierwsza to respondentki starające się

\footnotetext{
Większość respondentek krytykujących chustę wcześniej przyznała kobiecie prawo do samodzielnego decydowania o swoim stroju. Wskazuje to na niekonsekwencję w wypowiadanych poglądach. Warto jednak rozważyć, czy taka niekonsekwentna postawa nie jest wyrazem sposobu interpretacji modernizacji przez badane. Idąc tym tropem, można stwierdzić, że to, co nowoczesne w rozumieniu respondentek, stoi w absolutnej opozycji do tego, co muzułmańskie. Nilüfer Göle zinterpretowała to jako dylemat „albo/albo” (eather/or). Jeśli chcesz być nowoczesna, nie możesz być muzułmanką i odwrotnie. Nowoczesność jako pojęcie wykreowane przez społeczeństwo zachodnie ma się nijak do wartości związanych z islamem, dlatego też stanowi zaprzeczenie religijności w kontekście islamu (Göle 2001).
} 
unikać oceny kobiet noszących zasłonę, wypowiadając się na temat samej chusty. Znaczna część z nich uważa, że zasłona jest symbolem i elementem dyskryminacji kobiet. Dają one kobiecie prawo do noszenia jej, przyznając jednak, że wiele z nich jest do tego zmuszanych. Druga grupa to respondentki demonizujące zasłonę i wymierzające swoją krytykę w kobiety zakrywające się. Część z nich jednoznacznie klasyfikuje kobiety noszące chusty jako mniej wykształcone i niemające wiedzy o świecie. Jedna z nich, studentka antropologii, uznająca dowolność stroju, opowiada historię swojego kuzyna i jego dziewczyny:

R: Mój kuzyn ma dziewczynę... zakrywającą się... i chce się z nią ożenić, ale moja rodzina oponuje, z powodu zasłony...

B: Czy twoja rodzina mogłaby nie zaakceptować zasłaniającej się kobiety?

R: Tak... nie! Ja mogę z nimi żyć, ale... One są.. Jak... Jest wielki dystans między nami... Możemy żyć razem, ale nie możemy rozumieć się zbyt dobrze. Ich sposób życia jest inny. One mają dziwne zasady znowu... nie są zbyt zsekularyzowane... żyją w innych miejscach, robią inne rzeczy...

B: Na przykład?

R: Zostają w domu... One nie pracują. My jesteśmy równe, wchodzimy w relacje z kobietami i z mężczyznami... z obydwojgiem... Ja mam chłopaka, one nie mogą.

B: Ale dziewczyna twojego kuzyna ma chłopaka.

R: Tak, ale jej rodzina tego nie akceptuje!! Restrykcyjnie jej tego zabronili! Nie mogą się widywać teraz. Ona jest trzymana w domu... Rozmawiają tylko przez telefon.

B: Zaakceptowałabyś ją w Twojej rodzinie czy nie?

R: Tak! Mogę ją zaakceptować, jasne... Ale problem w tym, jak oni będą żyć razem!

B: Co masz na myśli?

R: Ponieważ mój kuzyn jest... zsekularyzowany... Nienawidzi zasłony... Może ona przestanie się zakrywać... To możliwe... Ale problem nie leży w zasłonie, to tylko symbol... Tu chodzi o jej styl życia. Ona żyje w Feratpaşa. Nigdy nie była w Kadiköy... i ona... Myślę, że nie mogłaby zrozumieć, że on pije alkohol. Mogą próbować, jasne... Będę im kibicować... Ale to może być trudne... (R13).

Wypowiedź ta potwierdza popularną w tureckim dyskursie antropologicznym tezę, o dystansowaniu się kemalistek do kobiet noszących zasłonę (Göle 1996; Göle 2001; Özyürek 2004). Respondentka wprowadza wyraźne rozgraniczenie na kategorie „my” i „one”, gdzie „my” to kobiety zsekularyzowane, nowoczesne, wykształcone, podczas gdy „one” to zasłaniające się, uwięzione $\mathrm{w}$ patriarchacie, niewykształcone kobiety z zamkniętymi umysłami i małą wiedzą o świecie. Taki sposób myślenia jest niezwykle stereotypowy i krzywdzący, jednak dość popularny w Turcji. Należy zaznaczyć, że respondentka ta podjęła jednak próbę bycia obiektywną, przyznała, że zaakceptuje dziewczynę swojego kuzyna w rodzinie, jednak towarzyszące tej wypowiedzi poglądy zdradzają jej uprzedzenia do kobiet noszących zasłonę. Uprzedzenia takie wykazuje także kilka innych rozmówczyń, w tym dwie deklarujące się jako muzułmanki. Uważają one, że chusta jest symbolem politycznym, nie religijnym, a kobiety noszące ją to zwolenniczki rządzącej obecnie w Turcji partii islamistycznej $\mathrm{AKP}^{8}$.

\footnotetext{
8 Adalet ve Kalkınma Partisi - Partia Sprawiedliwości i Rozwoju.
} 
Powyższe elementy światopoglądu badanych charakteryzują bardzo typowy dla Turcji problem - polisymboliczność zasłony jako znaku religijnego, politycznego, ale i sugerującego określony styl życia (Göle 2001; Kowalska 2009) oraz przynależność kulturową i etniczną (Hoodfar 2007). Owa polisymboliczność zasłony pojawiała się także w rozmowach z innymi studentkami. Respondentki chustę muzułmańską uważały za: symbol religijny (12) ${ }^{9}$, symbol polityczny (8), symbol niskiego wykształcenia (6), symbol tradycyjnego sposobu życia (6), symbol antymodernizacji (7) oraz symbol dyskryminacji ze względu na płeć (10). Te dane empiryczne potwierdzają, że chusta muzułmańska urosła do rangi symbolu antymodernizacji w Turcji. Zasłona - obecna w meczetach, na ulicach, w życiu codziennym - pojawiła się także w dyskusjach politycznych, przez co z symbolu religijnego przeistoczyła się w polisymbol tradycjonalizmu i konserwatyzmu. Wypowiedzi respondentek charakteryzuje pewien strach przed obecnością islamu w przestrzeni publicznej. Jego źródłem może być troska o to, by Turcji nie spotkał los Iranu, który po przemianach modernizacyjnych na skutek rewolucji islamskiej stał się państwem opartym na szariacie (Göle 2001). Dodatkowo niechęć wobec obecności islamu w sferze publicznej jest potęgowana przez ideologię zaszczepioną przez Atatürka „dzieciom modernizacji” - pierwszemu pokoleniu młodych w demokratycznej republice tureckiej, którzy stali się nauczycielami ideologii wyznawanej przez Kemala, przekazując ją swoim potomkom (Özyürek 2004).

Jak wskazałam, dziesięć respondentek przyznało muzułmańskiej chuście znaczenie związane z dyskryminacją kobiet. Temat ten, mimo że nie był poruszany bezpośrednio, wyraźnie pojawiał się w rozmowach z badanymi. Respondentki wskazywały na problem związany z nierównymi przywilejami seksualnymi kobiet i mężczyzn. Część z nich twierdziła, że obyczajowość związana z przedślubną abstynencją seksualną dotyczy jedynie przedstawicielek płci żeńskiej. Mówiły, że mężczyźni nie są nią objęci, mogą zachowywać się swobodnie, nie obawiając się sankcji ze strony społeczeństwa lub rodziny. Taka nierówność między sytuacją kobiet i mężczyzn może mieć źródło w ugruntowanym w obyczajowości poglądzie, że to kobieta jest odpowiedzialna za grzechy seksualne mężczyzny, gdyż prowokuje go swoim wyglądem bądź zachowaniem (Delaney 1991). Obok większej swobody seksualnej mężczyzn, prawie wszystkie respondentki (czternaście osób) podkreślały swój sprzeciw wobec idei posłuszeństwa kobiet mężczyznom, a także nie zgadzały się na przemoc mężczyzn w stosunku do kobiet.

Równouprawnienie jest zatem sprawą istotną dla samych badanych. Znaczący jest fakt, że dostrzegają one problemy związane z nieuprzywilejowaną pozycją kobiety w społeczeństwie, nie godząc się na nią. Wzrost świadomości praw kobiet dotyczy jednak nie tylko grupy badanych, lecz także całego społeczeństwa tureckiego. Coraz mniejszy odsetek kobiet uważa przemoc ze strony mężczyzn za rzecz normalną, krytykując dualne standardy moralności dla obu płci (Gül Altinay, Arat 2009).

9 Liczby w nawiasach odpowiadają liczbie respondentek przypisujących dane znaczenie chuście muzułmańskiej. Wzięłam pod uwagę wszystkie znaczenia, jakie dana respondentka przypisuje zasłonie, dlatego suma liczb w nawiasach nie odpowiada liczbie respondentek. 


\section{PODSUMOWANIE}

Dzisiaj wiadomo, że reformy Atatürka nie przyniosły pełnej sekularyzacji państwa, gdyż islam wciąż istotnie wpływa na struktury państwowe, prawodawstwo i obyczajowość turecką (Shankland 1999). Ogromna dychotomia pomiędzy wyznawcami ideologii kemalistycznej a zorientowanymi na odwołujący się do wartości muzułmańskich dyskurs obecnego rządu Turcji jest wyraźnie widoczna. Przestrzeń publiczną w dzisiejszej Turcji wypełniają zarówno tradycyjnie ubrane muzułmanki, jak i kobiety w nowoczesnych strojach. Obok tych ostatnich na ulicach miast można powszechnie spotkać muzułmanki noszące zachodnie ubrania dobrane tak, że odpowiadają one wymogom stawianym kobiecie przez islam.

$\mathrm{Na}$ podstawie analizy literatury przedmiotu wnioskuję, że społeczeństwo tureckie jest wyraźnie rozdarte pomiędzy Wschodem a Zachodem, tradycją a nowoczesnością. W związku z dualizmem wpływów musiało ono adaptować poszczególne idee pochodzące z dwóch odmiennych dyskursów: nowoczesnego, politycznego i tradycyjnego, religijnego, łącząc je w możliwie logiczny i pozwalający normalnie funkcjonować sposób. Analiza procesów modernizacji, które dotknęły Turcję, pozwala wyjaśnić napięcia w tożsamości, widoczne w wypowiedziach badanych kobiet. Respondentki, przekonane o swojej nowoczesności, w rzeczywistości łączą ze sobą sprzeczne idee, rozwiązując dylemat wyboru pomiędzy byciem muzułmanką a zmodernizowaną. Prezentują nowy model tureckiej kobiecości - ani nie religijny, ani nie zmodernizowany. Ta nowa jakość jest mieszanką patriarchalnej tradycji muzułmańskiej oraz nowoczesnych prądów myślowych Zachodu i stanowi odpowiedź na niejasne oczekiwania politycznego i religijnego dyskursu względem roli kobiety w przestrzeniach publicznej i prywatnej w Turcji.

\section{BIBLIOGRAFIA}

Ahmad, Feroz. 2003. Turkey. The quest for identity, Oxford: One world.

Anthias, Floya i Nira Yuval-Davis. 1989. Introduction to Women - Nation - State, w: Floya Anthias i Nira Yuval-Davis (eds.), Women - Nation - State, London: Macmillian.

Chmielowska, Danuta i Asıye Kılıç-Eryılmaz. 2001. Społeczna i rodzinna sytuacja kobiety tureckiej, w: Danuta Chmielowska, Barbara Grabowska i Ewa Machut-Mendecka (red.), Być kobieta w Oriencie, Warszawa: Dialog, s. 46-55.

Delaney, Carol. 1991. The Seed and The soil - Gender and Cosmology in Turkish Village Society, Oxford: University of California Press.

Durakbaşa Ayşe. 1997. Kemalism as identity politics in Turkey, w: Arat Zehra (ed.), Deconstructing image of ,, the Turkish woman”, New York: St. Martins Press, s. 139-155.

Erdoğlu Erkarslan, Özlem. 2011. Gender Roles at the Intersection of Public and Private Spheres: Transformation from Detached House to Apartment in Izmir, Turkey, w: Lori Brown (ed.), Feminist Practices: Interdisciplinary Approaches to Women in Architecture, Farnham: Ashagate Publishing Limited, s. 239-261.

Göle, Nilüfer. 1996. Forbidden Modern: civilization and veiling, Ann Arbor: University of Michigan Press. 
Göle, Nilüfer. 2001. Interview Nilufer Gole, PBS TV, dostęp online: http://www.pbs.org/wgbh/ pages/frontline/shows/muslims/interviews/gole.html [3.04.2012].

Gül Altinay, Ayşe and Yeşin Arat. 2009. Violence against woman in Turkey - A nationwide survey, Istanbul: Punto Publishing, dostęp online: Solutionshttp://www.kadinayoneliksiddet.org/KYS_ENG.pdf [11.04.2010].

Head, Jonathan. 2010. Quiet end to Turkey's college headscarf ban, dostęp online: http:// www.bbc.co.uk/news/world-europe-11880622 [3.04.2012].

Hoodfar, Homma. 2007. Zasłona w ich umysłach i na naszych głowach: muzulmanki i praktyki zasłaniania, w: Agnieszka Kościańska i Renata Hryciuk (red.), Gender: perspektywa antropologiczna, Warszawa: Wydawnictwo Uniwersytetu Warszawskiego, t. 1, s. 227-257.

Kowalska, Beata. 2009. O upadku imperium, republice i zastonie. Zmagania kobiet tureckich o autonomię, w: Beata Kowalska, Katarzyna Zielińska i Ben Koschalka (red.), Gender: Kobieta w kulturze i społeczeństwie, Kraków: Zakład Wydawniczy NOMOS, s. 105-132.

Machut-Mendecka, Ewa. 2001. Kobieta bez zasłony. Muzulmanka w świetle wiary i kultury, w: Danuta Chmielowska, Barbara Grabowska i Ewa Machut-Mendecka (red.), Być kobieta w Oriencie, Warszawa: Dialog, s. 18-33.

Mazurczyk, Agnieszka. 2009. Kulturalny tygiel - reportaż ze Stambutu. Miasto matych ojczyzn, dostęp online: http://www.polityka.pl/swiat/obyczaje/1501723,1,kulturalny-tygiel--reportazzestambulu.read?backTo=http://www.polityka.pl/swiat/analizy/1503526,1,turcjaile-armii-ile-islamu.read [10.03.2010].

Özyürek, Esra. 2004. Miniaturizing Atatürk. Privatization of state imagery and ideology in Turkey, „American Ethnologist” 31, 3, s. 374-391.

Raudvere, Catharina. 2003. Knowledge in Trust: Sufi Women in Istanbul, „Social Compass” 50, 1, s. 23-34.

Shankland, David. 1999. Islam and Society in Turkey, Huntingdon: Eothen Press.

Silverman, David. 2009. Interpretacja danych jakościowych, Warszawa: Wydawnictwo Naukowe PWN.

Stark, Rodney i Charles Glock. 1968. Wymiary zaangażowania religijnego, w: Władysław Piwowarski (red.), Socjologia religii. Antologia tekstów, Kraków: Zakład wydawniczy NOMOS, s. 182-188.

Thomson-DeVeaux, Amelia. 2010. Women In Turkish Universities Can Wear Headscarves Again, dostęp online: http://www.care2.com/causes/turkey-ends-ban-on-headscarves-inuniversities.html [3.04.2012].

WHO IS THE MODERN TURKISH WOMAN? HEADSCARVES, FEMININITY AND THE PATRIARCHY IN THE REPUBLIC OF TURKEY

\footnotetext{
The article examines the issue of women in the modern Republic of Turkey in the context of the processes of secularization and modernization, but also the patriarchal morality of the Muslim, which shape the outlook of Turkish citizens. My goal is to present tensions in the identities of Turkish women, caused due to the fact that they stay under the influence of two different discourses: traditional - Muslim discourse and modern kemalist one. I would like to present the transformation of the ideal of femininity that has taken place due to the secularization of the Turkish state. I will also focus on the issue of headscarves, which - as a result of two different discourses - have grown into an ambiguous symbol. In my analysis I take into account both the role
} 
of modernization in shaping the thinking of citizens as well as Islam, which disappeared from the public sphere, but still is an important determinant of the Turkish overlook. I will also base on the results of my fieldwork on the perceptions of the Muslim headscarf by the modern Turkish woman.

The first part of the paper is a presentation of the historical situation of Turkey with particularly emphasis on changes that have occurred due to the reforms of Mustafa Kemal Atatürk. I focus on the role of women in Turkey in the context of the background of historical events. I also present the entry of women into the public sphere in Turkey, which was accompanied by changes in mores and tensions that arise in the identity of the new Turkish women. The second part of the paper describes the results of my fieldwork on Muslim headscarves which I did among a group of young students of Yeditepe University in Istanbul. I am trying to show how the tensions in Turkish identity described in the literature are visible in the statements of my interlocutors. I refer also to ambiguity of veiling which significance has gone beyond the religious context.

Key words: Islam, feminity, religiousity, headscarves 